\title{
PELANGGARAN KODE ETIK DAN SANKSI DALAM PENYELENGGARAAN PEMILIHAN UMUM
}

\author{
Oleh \\ Dr. Tengku Erwinsyahbana, S.H., M.Hum \\ Tim Pemeriksa Daerah Provinsi Sumatera Utara \\ Dewan Kehormatan Penyelenggara Pemilu Republik Indonesia
}

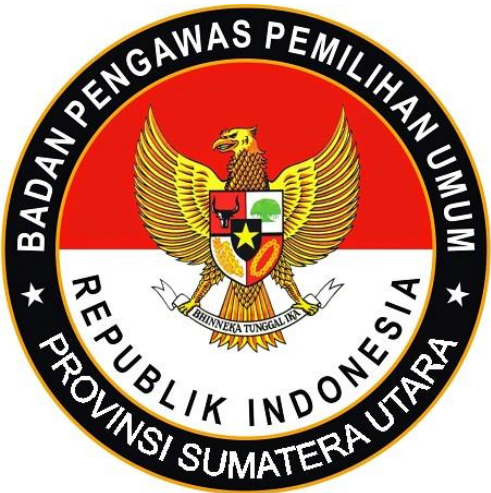

Disampaikan pada Rapat Kerja Teknis

Badan Pengawas Pemilihan Umum

Provinsi Sumatera Utara

Berastagi, 6-8 November 2015 


\section{PELANGGARAN KODE ETIK DAN SANKSI DALAM PENYELENGGARAAN PEMILIHAN UMUM}

\section{A. Pendahuluan}

Pemilihan umum atau yang disingkat dengan istilah "Pemilu", pada dasarnya merupakan kegiatan guna melaksanakan pemilihan seseorang atau beberapa orang, untuk dapat menduduki jabatan tertentu. Berdasarkan Pasal 1 angka 1 Undang-undang Nomor 8 Tahun 2012 tentang Pemilihan Umum Anggota Dewan Perwakilan Rakyat, Dewan Perwakilan Daerah, dan Dewan Perwakilan Rakyat Daerah (UU No. 8 Tahun 2012), ditegaskan bahwa: "Pemilihan umum, selanjutnya disebut Pemilu, adalah sarana pelaksanaan kedaulatan rakyat yang dilaksanakan secara langsung, umum, bebas, rahasia, jujur, dan adil dalam Negara Kesatuan Republik Indonesia berdasarkan Pancasila dan Undang-Undang Dasar Negara Republik Indonesia Tahun 1945".

Pasca reformasi dan amandemen UUDNRI 1945, pemilihan umum diselenggarakan untuk memilih anggota Dewan Perwakilan Rakyat, Dewan Perwakilan Daerah, Presiden dan Wakil Presiden dan Dewan Perwakilan Rakyat Daerah, ${ }^{1}$ dan sejak tahun 2004 penyelenggaraan Pemilu Presiden dan Wakil Presiden dilaksanakan secara langsung. Hal ini pula yang mengilhami dilaksanakannya pemilihan Kepala Daerah dan Wakil Kepala Daerah secara langsung.

\footnotetext{
${ }^{1}$ Lihat Pasal 22E ayat (2) UUDNRI 1945, yang menentukan bahwa Pemilihan umum diselenggarakan untuk memilih anggota Dewan Perwakilan Rakyat, Dewan Perwakilan Daerah, Presiden dan Wakil Presiden dan Dewan Perwakilan Rakyat Daerah.
} 
Pemilihan Kepala Daerah dan Wakil Kepala Daerah (selanjutnya disingkat Pilkada) secara langsung ini, tentunya didukung pula dengan semangat otonomi daerah yang telah digulirkan sejak tahun 1999, dan oleh sebab itu, sejak tahun 2005, telah diselenggarakan Pilkada secara langsung, baik di tingkat provinsi, maupun kabupaten/kota.

Fakta yang terjadi bahwa pelaksanaan Pilkada secara langsung banyak menimbulkan berbagai persoalan, sehingga Pemerintah telah beberapa kali mengganti peraturan perundang-undangan yang terkait dengan penyelenggaraan Pilkada, terakhir adalah dengan keluarnya Undang-undang Nomor 8 Tahun 2015 tentang Perubahan Atas Undangundang Nomor 1 Tahun 2015 tentang Penetapan Peraturan Pemerintah Pengganti Undang-undang Nomor 1 Tahun 2014 tentang Pemilihan Gubernur, Bupati, dan Walikota Menjadi Undang-undang (selanjutnya disingkat UU No. 8 Tahun 2015).

Ironisnya, walaupun pemerintah telah berupaya menerbitkan berbagai regulasi yang terkait dengan penyelenggaraan Pemilu, ternyata tetap saja masih sering terjadi adanya pelanggaran Pemilu yang dilakukan oleh oknum Penyelenggara Pemilu, dan salah satu jenis pelanggaran dimaksud adalah pelanggaran Kode Etik Pemilu. Hal ini dapat dibuktikan berdasarkan data yang ada pada Dewan Kehormatan Penyelenggara Pemilu Republik Indonesia (DKPP-RI), bahwa sejak bulan Juni 2012 sampai dengan Juni 2015, terdapat 1658 pengaduan dugaan pelanggaran Kode Etik Pemilu, dan secara lebih detail dapat dilihat pada tabel berikut: 
Tabel 1:

Jumlah Pengaduan Dugaan Pelanggaran Kode Etik Pemilu

Tahun 2012 s.d. 2015

\begin{tabular}{rcc}
\hline No. & Tahun & Jumlah Pengaduan \\
\hline 1. & 2012 & 99 \\
2. & 2013 & 606 \\
3. & 2014 & 879 \\
4. & 2015 & 74 \\
\hline \multicolumn{2}{l}{ Total } & $\mathbf{1 6 5 8}$ \\
\hline
\end{tabular}

Sumber: DKPP-RI Tahun 2015

Mengingat jumlah pengaduan yang begitu banyak dibanding jumlah Anggota DKPP yang hanya 7 orang, maka tidak mungkin DKPP dapat memeriksa keseluruhan perkara yang diadukan secara optimal, dan oleh sebab itu pada tahun 2014 DKPP-RI membentuk Tim Pemeriksa Daerah (TPD) untuk memeriksa kasus dugaan pelanggaraan Kode Etik Pemilu yang dilakukan Penyelengga Pemilu di tingkat kabupaten/kota.

Sejak TPD terbentuk, ada 417 pengaduan dugaan pelanggaraan Kode Etik Pemilu kepada DKPP, dan dari 417 kasus tersebut, ternyata pelanggaran Kode Etik Pemilu di Provinsi Sumatera Utara menduduki jumlah terbanyak kedua setelah Papua, yaitu sebanyak 73 pengaduan, sedangkan di Provinsi Papua sebanyak 82 pengaduan, ${ }^{2}$ bahkan pada tahun 2015, dibanding dengan Provinsi Papua, ternyata pengaduan untuk Provinsi Sumatera Utara lebih banyak, yaitu sebanyak 25 pengaduan, sedangkan di Papua hanya 17 pengaduan, yang secara lebih lengkap dapat dilihat pada tabel berikut: 2015.

${ }^{2}$ Jumlah pengaduan ini hanya untuk periode Juni 2014 sampai dengan Juni 
Tabel 2:

\section{Perbandingan Jumlah Pengaduan Dugaan Pelanggaran Kode Etik pada Provinsi Papua dan Sumatera Utara \\ Periode Juni 2014 s.d. Juni 2015}

\begin{tabular}{cccc}
\hline \multirow{2}{*}{ No. } & Provinsi & \multicolumn{2}{c}{ Tahun } \\
\cline { 2 - 3 } & & $\mathbf{2 0 1 4}$ & $\mathbf{2 0 1 5}$ \\
\hline 1. & Papua & 66 & 17 \\
2. Sumatera Utara & 48 & 25 \\
\hline Jumlah Total & $\mathbf{8 2}$ & $\mathbf{7 3}$ \\
\hline
\end{tabular}

Sumber: DKPP-RI Tahun 2015

Terkait dengan banyaknya jumlah kasus yang diadukan dan diperiksa oleh TPD seperti tabel tersebut di atas (khususnya Provinsi Sumatera Utara), diasumsikan dapat saja terjadi bahwa pelaksanaan penyelenggaraan Pemilu Kepala Daerah pada beberapa minggu yang akan datang, berpotensi menimbulkan banyak pengaduan dugaan pelanggaran Kode Etik Pemilu, bahkan telah ada beberapa kasus yang diperiksa oleh TPD terkait dengan penyelenggaraan Pemilu Kepada Daerah di Provinsi Sumatera Utara. Oleh sebab itu, diharapkan kepada seluruh jajaran Penyelenggara Pemilu di Sumatera Utara (termasuk Badan Pengawas Pemilu dan jajarannya), untuk selalu berpedoman pada regulasi yang telah ditetapkan.

\section{B. Kode Etik dalam Penyelenggaraan Pemilu}

Etika merupakan ilmu dan termasuk cabang dari filsafat yang paling tua sejak zaman Yunani Kuno. Etika adalah refleksi kritis, metodis, dan sistematis tentang tingkah laku manusia yang berkaitan dengan norma- 
norma atau tentang tingkah laku manusia dari sudut kebaikannya. Hal yang dibicarakan dan dianalisis dalam etika, adalah tema-tema sentral mengenai hati nurani, kebebasan, tanggung jawab, norma, hak dan kewajiban, serta nilai-nilai kebaikan. Lazimnya pengertian etika dirumuskan sebagai nilai-nilai dan norma-norma moral yang dipegang oleh seseorang atau sekelompok orang dalam masyarakat untuk mengatur tingkah lakunya, yang bertujuan untuk menciptakan hubungan antar manusia dalam masyarakat secara harmonis, dan oleh sebab itu "etika" selalu menuntun orang agar bersungguh-sungguh menjadi baik, agar memiliki sikap etis.

Terkait dengan Kode Etik Penyelenggara Pemilu, maka terhadap istilah "Kode Etik", diartikan sebagai satu kesatuan landasan norma moral, etis dan filosofis yang menjadi pedoman bagi perilaku penyelenggara pemilihan umum yang diwajibkan, dilarang, patut atau tidak patut dilakukan dalam semua tindakan dan ucapan. Adapun tujuan kode etik ini adalah untuk menjaga kemandirian, integritas, dan kredibilitas Penyelenggara Pemilu, yang sesuai dengan asas Penyelenggaraan Pemilu, yaitu: (1) mandiri; (2) jujur; (3) adil; (4) kepastian hukum; (5) tertib; (6) kepentingan umum; (7) keterbukaan; (8) proporsionalitas; profesionalitas; (10) akuntabilitas; (11) efisiensi; dan (12) efektivitas.

Berdasarkan Pasal 2 ayat (1) Peraturan Bersama Komisi Pemilihan Umum, Badan Pengawas Pemilihan Umum, dan Dewan Kehormatan Penyelenggara Pemilihan Umum Nomor 13 Tahun 2012 Nomor 11 Tahun 
2012 Nomor 1 Tahun 2012 tentang Kode Etik Penyelenggara Pemilihan Umum (selanjutnya disebut saja Peraturan Kode Etik Pemilu), telah ditentukan bahwa bahwa Kode Etik Pemilu ini berlandaskan pada: (1) Pancasila dan Undang-Undang Dasar Negara Republik Indonesia Tahun 1945; (2) Ketetapan Majelis Permusyawaratan Rakyat dan UndangUndang; (3) sumpah/janji jabatan sebagai Penyelenggara Pemilu; dan (4) asas Penyelenggara Pemilu.

Dalam Peraturan Kode Etik Pemilu, disebutkan ada 21 prinsip dasar yang merupakan kewajiban Penyelenggara Pemilu, yaitu:

1. Menjunjung tinggi Pancasila, Undang-Undang Dasar Negara Republik Indonesia Tahun 1945, dan peraturan perundang-undangan;

2. Menjunjung tinggi kepentingan bangsa dan Negara Kesatuan Republik Indonesia;

3. Menunjukkan penghargaan dan kerjasama dengan seluruh lembaga dan aparatur negara untuk kepentingan bangsa dan Negara Kesatuan Republik Indonesia;

4. Menjaga dan memelihara nama baik Negara Kesatuan Republik Indonesia;

5. Memelihara dan menjaga kehormatan lembaga Penyelenggara Pemilu;

6. Menjalankan tugas sesuai visi, misi, tujuan, dan program lembaga Penyelenggara Pemilu;

7. Menjaga rahasia yang dipercayakan kepadanya, termasuk hasil rapat yang dinyatakan sebagai rahasia sampai batas waktu yang telah 
ditentukan atau sampai masalah tersebut sudah dinyatakan untuk umum sepanjang tidak bertentangan dengan peraturan perundangundangan;

8. Menghargai dan menghormati sesama lembaga Penyelenggara Pemilu dan pemangku kepentingan Pemilu;

9. melakukan segala upaya yang dibenarkan etika sepanjang tidak bertentangan dengan perundang-undangan sehingga memungkinkan bagi setiap penduduk yang berhak memilih terdaftar sebagai pemilih dan dapat menggunakan hak memilihnya;

10. Menjaga dan memelihara tertib sosial dalam penyelenggaraan Pemilu;

11. Mengindahkan norma dalam penyelenggaraan Pemilu;

12. Menghormati kebhinnekaan masyarakat Indonesia.

13. Beriman dan bertaqwa kepada Tuhan Yang Maha Esa;

14. Menjunjung tinggi sumpah/janji jabatan dalam melaksanakan tugas, wewenang, kewajiban, dan tanggungjawabnya;

15. Menjaga dan memelihara netralitas, imparsialitas, dan asas-asas penyelenggaraan Pemilu yang jujur, adil, dan demokratis;

16. Tidak mengikutsertakan atau melibatkan kepentingan pribadi maupun keluarga dalam seluruh pelaksanaan tugas, wewenang, kewajibannya;

17. Melaksanakan tugas-tugas sesuai jabatan dan kewenangan yang didasarkan pada Undang-Undang Dasar Negara Republik Indonesia Tahun1945, undang-undang, peraturan perundang-undangan, dan keputusan yang berkaitan dengan penyelenggaraan Pemilu; 
18. Mencegah segala bentuk dan jenis penyalahgunaan tugas, wewenang, dan jabatan, baik langsung maupun tidak langsung;

19. Menolak untuk menerima uang, barang, dan/atau jasa atau pemberian lainnya yang apabila dikonversi melebihi standar biaya umum dalam jangka waktu paling lama 3 (tiga) jam, dalam kegiatan tertentu secara langsung maupun tidak langsung dari calon peserta Pemilu, peserta Pemilu, calon anggota DPR dan DPRD, dan tim kampanye;

20. Mencegah atau melarang suami/istri, anak, dan setiap individu yang memiliki pertalian darah/semenda sampai derajat ketiga atau hubungan suami/istri yang sudah bercerai di bawah pengaruh, petunjuk, atau kewenangan yang bersangkutan, untuk meminta atau menerima janji, hadiah, hibah, pemberian, penghargaan, dan pinjaman atau bantuan apapun dari pihak yang berkepentingan dengan penyelenggaraan Pemilu;

21. Menyatakan secara terbuka dalam rapat apabila memiliki hubungan keluarga atau sanak saudara dengan calon, peserta Pemilu, atau tim kampanye.

Dalam Peraturan Kode Etik Pemilu diatur pula tentang pelaksanaan Prinsip Dasar Etika dan Perilaku bagi penyelenggara Pemilu, yaitu:

1. Dalam melaksanakan asas mandiri dan adil, Penyelenggara Pemilu berkewajiban:

a. bertindak netral dan tidak memihak terhadap partai politik tertentu, calon, peserta pemilu, dan media massa tertentu; 
b. memperlakukan secara sama setiap calon, peserta Pemilu, calon pemilih, dan pihak lain yang terlibat dalam proses Pemilu;

c. menolak segala sesuatu yang dapat menimbulkan pengaruh buruk terhadap pelaksanaan tugas dan menghindari dari intervensi pihak lain;

d. tidak mengeluarkan pendapat atau pernyataan yang bersifat partisan atas masalah atau isu yang sedang terjadi dalam proses Pemilu;

e. tidak mempengaruhi atau melakukan komunikasi yang bersifat partisan dengan pemilih;

f. tidak memakai, membawa, atau mengenakan simbol, lambang atau atribut yang secara jelas menunjukkan sikap partisan pada partai politik atau peserta Pemilu tertentu;

g. tidak memberitahukan pilihan politiknya secara terbuka dan tidak menanyakan pilihan politik kepada orang lain;

h. memberitahukan kepada seseorang atau peserta Pemilu selengkap dan secermat mungkin akan dugaan yang diajukan atau keputusan yang dikenakannya;

i. menjamin kesempatan yang sama kepada setiap peserta Pemilu yang dituduh untuk menyampaikan pendapat tentang kasus yang dihadapinya atau keputusan yang dikenakannya; 
j. mendengarkan semua pihak yang berkepentingan dengan kasus yang terjadi dan mempertimbangkan semua alasan yang diajukan secara adil;

k. tidak menerima hadiah dalam bentuk apapun dari peserta Pemilu, calon peserta Pemilu, perusahaan atau individu yang dapat menimbulkan keuntungan dari keputusan lembaga penyelenggara Pemilu.

2. Dalam melaksanakan asas kepastian hukum, Penyelenggara Pemilu berkewajiban:

a. melakukan tindakan dalam rangka penyelenggaraan Pemilu yang secara tegas diperintahkan oleh peraturan perundang-undangan;

b. melakukan tindakan dalam rangka penyelenggaraan Pemilu yang sesuai dengan yurisdiksinya;

c. melakukan tindakan dalam rangka penyelenggaraan Pemilu, menaati prosedur yang ditetapkan dalam peraturan perundangundangan;

d. menjamin pelaksanaan peraturan perundang-undangan yang berkaitan dengan Pemilu sepenuhnya diterapkan secara tidak berpihak dan adil.

3. Dalam melaksanakan asas jujur, keterbukaan, dan akuntabilitas, Penyelenggara Pemilu berkewajiban:

a. menjelaskan keputusan yang diambil berdasarkan peraturan perundangundangan, tata tertib, dan prosedur yang ditetapkan; 
b. membuka akses publik mengenai informasi dan data yang berkaitan dengan keputusan yang telah diambil sesuai peraturan perundangundangan;

c. menata akses publik secara efektif dan masuk akal serta efisien terhadap dokumen dan informasi yang relevan sesuai ketentuan peraturan perundang-undangan;

d. menjelaskan kepada publik apabila terjadi penyimpangan dalam proses kerja lembaga penyelenggara Pemilu serta upaya perbaikannya;

e. menjelaskan alasan setiap penggunaan kewenangan publik;

f. memberikan penjelasan terhadap pertanyaan yang diajukan mengenai keputusan yang telah diambil terkait proses Pemilu; dan

g. memberikan respon secara arif dan bijaksana terhadap kritik dan pertanyaan publik.

4. Dalam melaksanakan asas kepentingan umum, Penyelenggara Pemilu berkewajiban:

a. memberikan informasi dan pendidikan pemilih yang mencerahkan pikiran dan kesadaran pemilih;

b. memastikan pemilih memahami secara tepat mengenai proses Pemilu;

c. membuka akses yang luas bagi pemilih dan media untuk berpartisipasi dalam proses penyelenggaraan Pemilu; 
d. menciptakan kondisi yang kondusif bagi pemilih untuk menggunakan hak pilihnya atau memberikan suaranya; dan

e. memastikan ketersediaan sarana dan prasarana pendukung bagi pemilih yang membutuhkan perlakuan khusus dalam menggunakan dan menyampaikan hak pilihnya.

5. Dalam melaksanakan asas proporsionalitas, Penyelenggara Pemilu berkewajiban:

a. mengumumkan adanya hubungan atau keterkaitan pribadi yang dapat menimbulkan situasi konflik kepentingan dalam pelaksanaan tugas penyelenggara Pemilu;

b. menjamin tidak adanya penyelenggara Pemilu yang menjadi penentu keputusan yang menyangkut kepentingan sendiri secara langsung maupun tidak langsung;dan

c. tidak terlibat dalam setiap bentuk kegiatan resmi maupun tidak resmi yang dapat menimbulkan konflik kepentingan.

6. Dalam melaksanakan asas profesionalitas, efisiensi, dan efektivitas, Penyelenggara Pemilu berkewajiban:

a. menjamin kualitas pelayanan kepada pemilih dan peserta sesuai dengan standar profesional administrasi penyelenggaraan Pemilu;

b. bertindak berdasarkan standar operasional prosedur dan substansi profesi administrasi Pemilu;

c. bertindak hati-hati dalam melakukan perencanaan dan penggunaan anggaran agar tidak berakibat pemborosan dan penyimpangan; 
d. melaksanakan tugas sebagai penyelenggara Pemilu dengan komitmen tinggi;

e. menggunakan waktu secara efektif sesuai alokasi waktu yang ditetapkan oleh penyelenggara Pemilu;

f. tidak melalaikan pelaksanaan tugas yang diatur dalam organisasi penyelenggara Pemilu; dan

g. menggunakan keuangan yang bersumber dari APBN dan APBD atau yang diselenggarakan atas tanggungjawab Pemerintah dalam melaksanakan seluruh kegiatan penyelenggaraan Pemilu.

7. Dalam melaksanakan asas tertib, Penyelenggara Pemilu berkewajiban:

a. memastikan seluruh informasi yang disampaikan kepada publik berdasarkan data dan/atau fakta;

b. memastikan informasi yang dikumpulkan, disusun, dan disebarluaskan dengan cara sistematis, jelas, dan akurat;

c. memberikan informasi mengenai Pemilu kepada publik secara lengkap, periodik dan dapat dipertanggungjawabkan; dan

d. memberitahu kepada publik mengenai bagian tertentu dari informasi yang belum sepenuhnya dapat dipertanggungjawabkan berupa informasi sementara

\section{Sanksi-sanksi dalam Pelanggaran Kode Etik Pemilu}

Sebelumnya perlu pula dipahami bahwa antara sanksi pelanggaran hukum dengan sanksi pelanggaran etika adalah berbeda, karena menurut 
American Speech Language Hearing Assocation (ASHA) sebagaimana dikutip Jimly Asshiddiqie, bahwa dalam sistem sanksi etika, bentuk sanksi yang dapat diterapkan adalah: ${ }^{3}$

1. Reprimand atau teguran;

2. Cencure atau pernyataan atau mosi tidak percaya yang dinyatakan secara terbuka dan dipublikasikan di media asosiasi untuk diketahui oleh sesama anggota dan masyarakat luas;

3. Revocation atau pencabutan status keanggotaan untuk waktu tertentu, yaitu selama 5 (lima) tahun atau dapat pula dijatuhkan untuk seumur hidup (sampai meninggal dunia);

4. Suspension atau penangguhan keanggotaan untuk sementara waktu;

5. Withholding atau sanksi penangguhan proses registrasi keanggotaan; dan

6. Cease and desist orders atau sebagai tambahan bentuk sanksi lain.

Sehubungan dengan bentuk sanksi yang disebutkan di atas, Jimly Asshiddiqie juga mengatakan bahwa fungsi sanksi etika lebih bersifat pencegahan, selain juga penindakan. Sanksi etika biasanya ditentukan berupa teguran atau peringatan yang bertingkat, mulai dari teguran lisan, teguran tertulis atau teguran ringan dan teguran keras. Bahkan kadangkadang ditentukan pula bahwa teguran itu dapat dijatuhkan secara bertahap atau bertingkat, misalnya teguran pertama, teguran kedua dan teguran tingkat terakhir. Bentuk sanksi yang paling keras karena tingkat keseriusan atau beratnya pelanggaran etik yang dilakukan oleh seorang aparat atau pemegang jabatan publik (ambts-dragger), adalah sanksi pemberhentian atau pemecatan seseorang dari jabatan publik yang bersangkutan, ${ }^{4}$ tetapi khusus terhadap pelanggaran kode etik Pemilu,

${ }^{3}$ JimlyAsshiddiqie, Peradilan Etik dan Etika Konstitusi, Perspektif Baru tentang Rule of Law and Rule of Ethics \& Constitutional Law and Constitutional Ethics, Sinar Grafika, Jakarta, 2014, hlm. 78-80.

${ }^{4}$ Ibid., hlm. 58. 
maka dalam Peraturan Kode Etik Pemilu, telah ditentukan bahwa sanksi pelanggaran Kode Etik Pemilu, terdiri dari: (1) teguran tertulis; (2) pemberhentian sementara; atau (3) pemberhentian tetap.

\section{Penutup}

Adanya fakta dan pengalaman bahwa di Provinsi Sumatera Utara terdapat banyak pengaduan kasus dugaan pelanggaran Kode Etik Pemilu yang sudah diperiksa dan diputus oleh DKPP-RI, maka dalam pelaksana Pemilu Kepala Daerah juga berpotensi besar untuk adanya pengaduan dugaan pelanggaran Kode Etik Pemilu. Oleh sebab itu, kepada seluruh Penyelenggara Pemilu agar tetap mempedomani dan mengindahkan asas-asas, prinsip-prinsip dasar, dan pelaksanaan prinsip-prinsip dasar Pemilu sebagaimana yang ditetapkan dalam Peraturan Kode Etik Pemilu, serta peraturan-peraturan atau regulasi-regulasi lain yang terkait dengan penyelenggaraan Pemilu. 


\section{DAFTAR PUSTAKA}

JimlyAsshiddiqie. 2014. Peradilan Etik dan Etika Konstitusi, Perspektif Baru tentang Rule of Law and Rule of Ethics \& Constitutional Law and Constitutional Ethics. Jakarta: Sinar Grafika.

Republik Indonesia, Undang Undang Dasar 1945

Republik Indonesia, Undang-undang Nomor 8 Tahun 2012 tentang Pemilihan Umum Anggota Dewan Perwakilan Rakyat.

Republik Indonesia, Peraturan Pemerintah Pengganti Undang-undang Nomor 1 Tahun 2014 tentang Pemilihan Gubernur, Bupati, dan Walikota.

Republik Indonesia, Undang-undang Nomor 8 Tahun 2015 tentang Perubahan Atas Undang-undang Nomor 1 Tahun 2015 tentang Penetapan Peraturan Pemerintah Pengganti Undang-undang Nomor 1 Tahun 2014 tentang Pemilihan Gubernur, Bupati, dan Walikota Menjadi Undang-undang.

Republik Indonesia, Peraturan Bersama Komisi Pemilihan Umum Nomor 13 Tahun 2012, Badan Pengawas Pemilihan Umum Nomor 11 Tahun 2012 dan Dewan Kehormatan Penyelenggara Pemilihan Umum Nomor 1 Tahun 2012, tentang Kode Etik Penyelenggara Pemilihan Umum 


\title{
DATA NARASUMBER
}

\author{
Nama $\quad$ : Dr. Tengku Erwinsyahbana, SH, M.Hum \\ Tempat/Tanggal Lahir : Tapanuli Selatan, 6 Juli 1968 \\ Pekerjaan $\quad: 1$. Dosen Fakultas Hukum UMSU \\ 2. Tim Pemeriksa Daerah Provinsi Sumatera \\ Utara (DKPP-RI) \\ Alamat \\ : Asrama Kodam I/BB, Jl. Prasaja No. K-281 \\ Medan \\ Pendidikan \\ : S.1 Fakultas Hukum Univ. Andalas di Padang \\ S.2 Pascasarja USU di Medan \\ S.3 Pascasarjana Univ. Padjadjaran di Bandung
}

